\title{
PENINGKATAN AKTIVITAS SISWA DAN HASIL BELAJAR KOGNITIF BIOLOGI MELALUI PENGGUNAAN MODEL PEMBELAJARAN BERBASIS MASALAH
}

\author{
Syamsiara Nur \\ Jurusan Pendidikan Biologi FMIPA Universitas Sulawesi Barat \\ E-mail: nur_syamsiara@yahoo.co.id
}

\begin{abstract}
Abstrak
Penelitian ini merupakan penelitian tindakan kelas (Classroom Action Research) yang bertujuan untuk meningkatkan Aktivitas dan hasil belajar kognitif biologi melalui penggunaan model Pembelajaran Berbasis Masalah. Instrumen penelitian yang digunakan dalam penelitian ini adalah lembar observasi aktivitas siswa, dan hasil belajar kognitif dalam bentuk pilihan ganda. Teknik pengumpulan data meliputi lembar observasi aktivitas pengamatan siswa, dan tes hasil belajar yang dianalisis secara kuantitatif dengan persentase. Penelitian ini dilakukan melalui 2 siklus, tiap siklus ada 4 tahapan yaitu perencanaan, pelaksanaan, pengamatan dan tindakan. Hasil penelitian ini menunjukkan bahwa penerapan model Pembelajaran Berbasis Masalah dapat meningkatkan aktivitas belajar siswa dengan nilai rata-rata siklus I 65,63 dan pada siklus II meningkat menjadi 87,71, dan meningkatkan hasil belajar kognitif biologi dengan persentase ketuntasan belajar pada siklus I sebesar 36,7\%, pada siklus II meningkat menjadi 90\%. Kesimpulan dari hasil penelitian ini yaitu model Pembelajaran Berbasis Masalah dapat meningkatkan Aktivitas siswa dan hasil belajar kognitif biologi siswa.
\end{abstract}

Kata Kunci : Model Pembelajaran Berbasis Masalah, Aktivitas Belajar, Respon Siswa, Kemampuan Pemecahan Masalah, dan Hasil Belajar.

\section{PENDAHULUAN}

Pendidikan merupakan salah satu faktor penunjang yang sangat penting bagi perkembangan perubahan peradaban manusia dalam suatu bangsa. Bangsa yang mempunyai peradaban maju adalah bagian yang mempunyai sumber daya manusia yang berkualitas. Dalam persaingan global, bangsa Indonesia sebagai bangsa yang berdaulat perlu berpacu untuk terus mengembangkan dan meningkatkan kualitas sumber daya manusia sehingga dapat diperhitungkan dimata dunia. Oleh karena itu, peningkatan kualitas sumber daya manusia merupakan kewajiban yang harus dilakukan secara terencana, terarah, intensif, efektif dan efisien dalam proses pembangunan, kalau tidak ingin bangsa ini kalah dalam menjalani era globalisai tersebut (Tilaar, 2002).

Pergeseran paradigma proses pendidikan dari pengajaran ke pembelajaran telah memberi tantangan baru bagi guru dalam melaksanakan tugasnya di kelas. Peserta didik yang akan di fasilitasi untuk mencapai hasil belajar atau kompetensi yang di harapkan tidak semunya memiliki karakteristik dan kemampuan yang sama. Demikian pula, bahwa tidak semua unsur penunjang belajar tiap sekolah sama. Hal tersebut menjadi hambatan belajar bagi siswa jika tidak diatasi secara tepat. Tindakan yang dapat dilakukan untuk mengatasinya adalah menggunakan berbagai pendekatan, metode, media, dan sarana pendukung lainnya yang disesuaikan dengan jenis dan sifat hambatan belajar yang dihadapi oleh peserta didik.

Aktivitas belajar mengajar yang berlangsung dalam kelas dikendalikan langsung oleh guru. Oleh sebab itu, guru dituntut untuk lebih kreatif dalam mengamati berbagai persoalan yang terjadi saat proses berlangsung. Berdasarkan hasil pengamatan tersebut diharapkan guru akan mampu melakukan berbagai inovasi pembelajaran, baik berupa pendekatan, metode, dan media yang dapat diterapkan saat mengajar siswa dengan karakteristik bahan ajar dan kondisi siswa yang di ajar.

Mata pelajaran biologi seperti halnya pelajaran lainnya memiliki karakteristik tertentu. Ilmu biologi merupakan pengetahuan teoritis tentang meteri yang kebenarannya dapat dijelaskan dengan logika metematika. Sebagian aspeknya bersifat kasat mata yang dapat dibuat fakta kongkritnya dan sebagian aspek yang lain bersifat abstrak, akan tetapi kebenarannya tetap dapat dibuktikan dengan logika matematika sehingga rasionalitasnya dapat dirumuskan atau diformulasikan. Karakteritik ini harus dipahami oleh guru sebagai dasar untuk menyusun strategi pembelajarannya. Dengan 
mempelajari karakteristik setiap materi atau konsep yang akan diajarkan oleh seorang guru biologi, maka diharapkan dapat memilih model, pendekatan, dan metode yang sesuai serta mengembangkan berbagai media pembelajaran yang dapat memudahkan siswa untuk memahaminya.

Pembelajaran berbasis masalah merupakan suatu model pembelajaran yang menggunakan masalah-masalah dunia nyata sebagai suatu konteks bagi siswa untuk belajar tentang cara berpikir kritis dan keterampilan memecahkan masalah, serta untuk memperoleh pengetahuan dan konsep esensial dari materi pelajaran. Bentuk pembelajaran berbasis masalah seperti ini dapat mengarahkan siswa untuk bekerja tidak hanya sekedar mencari masalah dan menjawab masalah tersebut dengan benar, akan tetapi lebih jauh bagaimana dengan masalah tersebut siswa dapat mengkonstruksi pengetahuannya dan belajar dengan pengalaman yang diperolehnya (Rusman, 2010)

\section{METODE PENELITIAN}

Penelitian ini merupakan penelitian tindakan kelas (Classroom Action Research) berupa pembelajaran berbasis masalah. Sesuai dengan hakikat PTK, maka prosedur pelaksanaan penelitian untuk masing-masing siklus melalui tahapan-tahapan: perencanaan (planning), pelaksanaan tindakan (action), observasi (observation), evaluasi (evaluation) dan refleksi (reflection).

\section{Istrumen Penelitian:}

Instrumen yang digunakan dalam penelitian ini adalah Lembar pengamatan aktivitas siswa dan tes hasil belajar kognitif kognitif. Instrumen tersebut digunakan untuk mengumpulkan data-data yang diperlukan dalam penelitian. Berikut ini uraian dari instrumen yang digunakan dalam penelitian. Lembar Pengamatan Aktivitas Siswa

Lembar pengamatan aktivitas siswa digunakan untuk memperoleh informasi tentang kegiatan siswa saat berlangsungnya proses pembelajaran. Analisis hasil observasi terhadap aktivitas siswa dilakukan dengan menghitung frekuensi rata-rata dan persentase setiap aspek pada tiap pertemuan. Selanjutnya, aktivitas siswa selama pembelajaran merupakan rata-rata aktivitas siswa dalam satu siklus.

\section{HASIL DAN PEMBAHASAN}

\subsection{Hasil Pengamatan}

\subsubsection{Analisis Deskriptif Motivasi Belajar IPA Siswa}

Berdasarkan hasil penelitian terkait dengan motivasi siswa kelas IX SMPN 2 Batang melalui model pembelajaran kooperatif $C R H$ mengalami peningkatan berdasarkan analisis data hasil penelitian. Untuk melihat peningkatan tersebut, maka dapat dilihat pada Gambar 1 berikut.

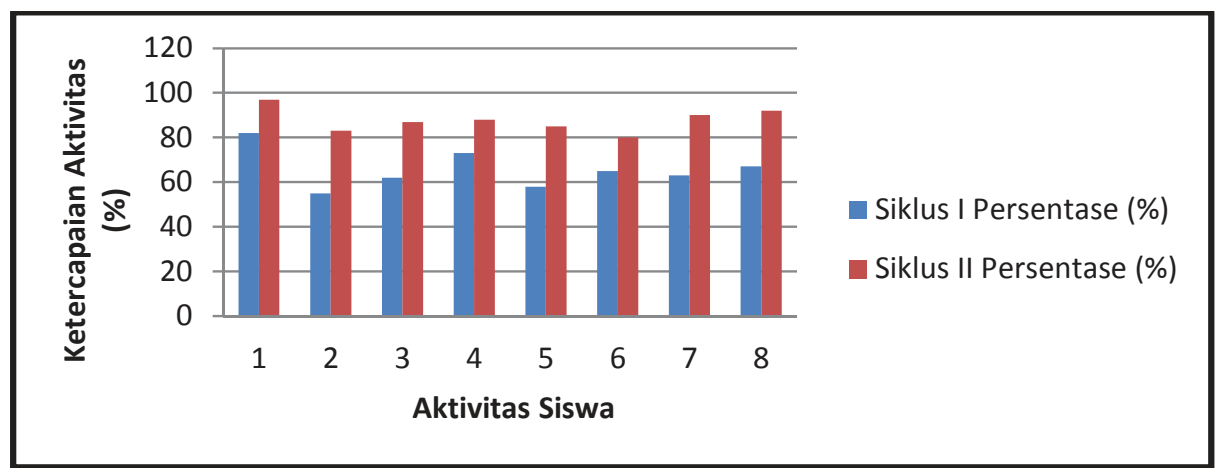

Gambar 1. Persentase Motivasi Belajar IPA Siswa

Gambar 1 memperlihatkan adanya peningkatan aktivitas siswa dari siklus I ke siklus II yang diajar melalui model pembelajaran Berbasis Masalah. 


\subsubsection{Analisis Deskriptif Hasil belajar kognitif Kognitif IPA Siswa}

Banyaknya siswa yang nilai hasil belajar kognitifnya dari siklus I ke siklus II mengalami peningkatan berarti persentase tingkat keberhasilan penelitian ini telah tercapai yaitu lebih dari $85 \%$ secara klasikal siswa tuntas belajar atau mencapai nilai KKM. Pada Gambar 2 di bawah ini merupakan diagram yang memperlihatkan hasil belajar kognitif kognitif IPA pada siklus I dan siklus II.

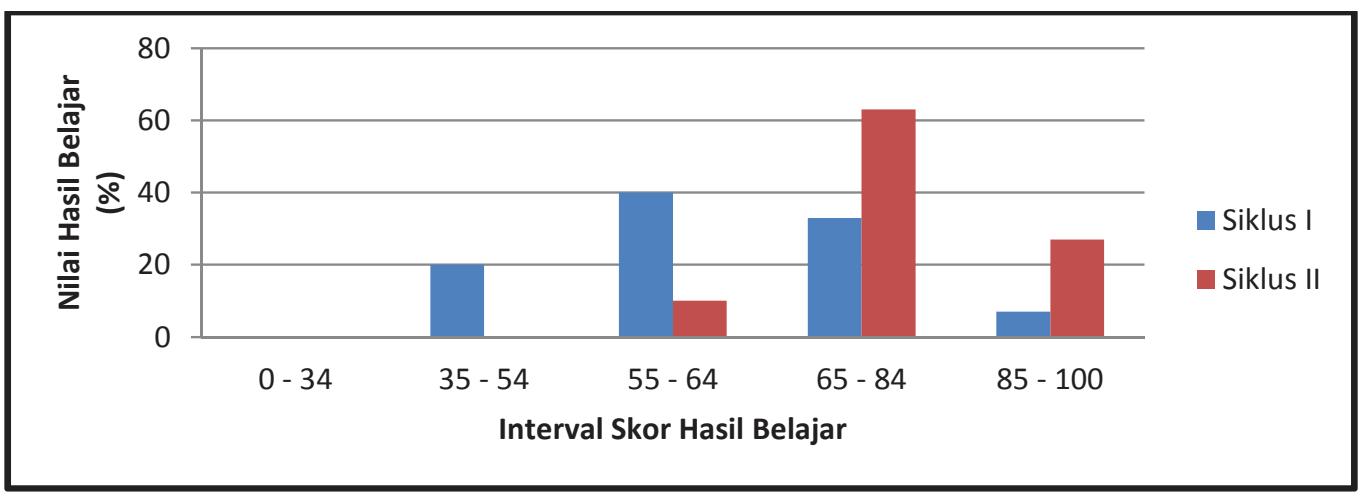

Gambar 2 Persentase Hasil belajar kognitif IPA Siswa Siklus I dan Siklus II

Gambar 2 tersebut mengungkapkan adanya peningkatan hasil belajar kognitif IPA yang diajar dengan melalui penerapan model pembelajaran Berbasis Masalah. Pada siklus I, rata-rata siswa memperoleh nilai pada kategori rendah, sedang, tinggi, dan sangat tinggi. Sedangkan pada siklus II, rata-rata siswa memperoleh nilai pada kategori sedang, tinggi, sangat tinggi.

\subsection{Pembahasan}

\subsubsection{Aktivitas Belajar Siswa}

Berdasarkan hasil pengamatan aktivitas siswa kelas $\mathrm{VII}_{\mathrm{A}}$ SMP Negeri 4 Wonomulyo selama proses pembelajaran terlihat adanya peningkatan aktivitas belajar siswa dari siklus I ke siklus II. Hal ini ditandai dengan meningkatnya peran aktif siswa selama proses pembelajaran dan persentase siswa yang melakukan kegiatan lain selama proses belajar mengajar berlangsung.

Rendahnya aktivitas siswa pada siklus I disebabkan karena pada siklus I tersebut, siswa masih belum bisa beradaptasi dengan model pembelajaran yang digunakan. Siswa pada umumnya masih sangat terpengaruh dengan model pembelajaran yang berpusat pada guru dan keaktifan siswa yang masih didominasi oleh siswa yang pintar saja. Selain itu juga, siswa masih selalu mengharapkan adanya remedial untuk perbaikan nilai sehingga aktivitas siswa tidak sesuai dengan model pembelajaran berbasis masalah. Sementara pada siklus II, siswa sudah mampu beradaptasi dengan model pembelajaran yang digunakan sehingga berefek pada meningkatnya aktivitas siswa.

Penggunaan model pembelajaran berbasis masalah secara umum dapat meningkatkan aktivitas siswa dari siklus I ke siklus II. Tabel 4.1 menunjukkan bahwa aktivitas siswa mengalami peningkatan dari siklus I ke siklus II, hal ini ditandai dengan meningkatnya peran aktif siswa dalam proses pembelajaran.

Terjadinya peningkatan persentase aktivitas siswa dari siklus I ke siklus II menunjukkan bahwa sebagian besar siswa memiliki perhatian yang besar dalam belajar biologi, khususnya dalam pembelajaran biologi yang menerapkan model pembelajaran berbasis masalah. Meningkatnya jumlah siswa yang melakukan aktivitas sesuai dengan komponen aktivitas seperti memperhatikan penjelasan guru, mendefenisikan masalah yang dihadapi, membaca dan mengerjakan tugas LKS dengan cermat, bekerja sama dengan kelompok, menyajikan hasil karya, memberikan pertanyaan pada saat diskusi antar kelompok, memberikan jawaban pada saat diskusi antar kelompok, dan menyimpulkan materi pelajaran menunjukkan adanya keinginan siswa untuk lebih memahami materi pelajaran.

Dalam penelitian ini ada delapan aktivitas yang diamati oleh dua orang observer. Setiap kategori pengamatan aktivitas siswa sesuai dengan model pembelajaran yang digunakan yakni model 
pembelajaran berbasis masalah. Pada kategori pengamatan aktivitas siswa yang keenam dan ketujuh memiliki pernyataan yang hampir sama.

Model pembelajaran berbasis masalah adalah model pembelajaran yang dimulai dengan adanya masalah, kemudian siswa memperdalam pengetahuannya tentang apa yang mereka telah ketahui dan apa yang perlu diketahui, selanjutnya bekerja sama dalam kelompok untuk mencari solusi bagi masalah yang dihadapi atau dengan kata lain merupakan model yang diawali dengan guru memperkenalkan siswa dengan situasi masalah dan diakhiri dengan penyajian hasil karya. Siswa benar-benar ditempatkan sebagai subjek yang belajar. Tugas guru adalah memilih masalah yang menarik, selanjutnya disampaikan kepada kelas untuk dipecahkan. Tugas guru selanjutnya adalah menyediakan sumber belajar bagi siswa dalam rangka memecahkan masalah. Bimbingan dan pengawasan guru, masih sangat diperlukan tetapi intervensi terhadap kegiatan siswa dalam pemecahan masalah harus dikurangi.

Penggunaan model pembelajaran berbasis masalah dapat mengaktifkan siswa untuk belajar. Hal ini ditandai dengan meningkatnya jumlah siswa yang mampu mendefenisikan masalah yang dihadapi, aktif bekerja sama dengan teman kelompoknya, membaca dan mengerjakan tugas LKS dengan cermat, memberikan pertanyaan dan jawaban pada saat diskusi, dan menyajikan hasil karya serta menyimpulkan materi pelajaran dari siklus I ke siklus II. Adanya beberapa siswa yang tidak mengerjakan tugas LKS yang diberikan pada siklus I karena siswa tersebut masih ragu untuk mengerjakannya karena terkendala dengan model pembelajaran yang diberikan. Sedangkan adanya siswa yang kurang aktif dalam kegiatan diskusi pada siklus I disebabkan karena siswa pada umumnya masih terpengaruh oleh model pembelajaran yang menerapkan sistem kompetisi, yaitu sistem pembelajaran yang menanamkan sikap bersaing. Hal tersebut terlihat dari sikap beberapa siswa yang cenderung mengerjakan tugas tanpa berdiskusi. Berbeda pada siklus II, siswa sudah memahami model pembelajaran yang diterapkan dan dalam diri anggota kelompok telah tertanam rasa saling menghargai satu sama lain.

Menurut Sanjaya (2007), siswa perlu di dorong untuk mau dan sanggup berinteraksi dan berkomunikasi dengan anggota lain. Siswa perlu dibantu mengatasi berbagai hambatan dalam berinteraksi dan berkomunikasi, sehingga setiap siswa dapat menyampaikan ide, mengemukakan pendapat, dan memberikan kontribusi kepada keberhasilan kelompok. Dengan demikian, interaksi antar siswa seputar tugas atau materi yang diberikan menjadi lebih besar sehingga siswa menjadi lebih aktif dalam kegiatan berdiskusi dengan kelompoknya.

Menurut Slavin (dalam Yusuf, 2007) mengemukakan bahwa pengajaran dapat dilakukan dengan memberikan siswa sejumlah bantuan selama tahap-tahap awal pembelajaran, kemudian mengurangi bantuan tersebut dan selanjutnya memberikan kesempatan kepada siswa tersebut untuk mengambil alih tanggung jawab yang semakin besar setelah ia dapat melakukannya. Aktivitas ini memberikan kontribusi positif terhadap siswa, sehingga jumlah siswa yang dapat menyelesaikan masalah dan mengerjakan soal tepat waktu menjadi meningkat dari siklus I ke siklus II.

Terjadinya peningkatan persentase aktivitas siswa dari siklus I ke siklus II menunjukkan bahwa sebagian besar siswa memiliki perhatian yang besar dalam belajar biologi, khususnya pembelajaran biologi dengan menggunakan model pembelajaran berbasis masalah. Peningkatan jumlah siswa yang mendefenisiskan masalah yang dihadapi, bekerja sama dengan kelompok, dan menyajikan hasil karya menunjukkan keinginan siswa untuk lebih memahami materi pelajaran dan memecahkan permasalahan yang mereka hadapi. Peningkatan aktivitas bertanya, menjawab dan menganggapi pertanyaan kelompok lain serta penurunan aktivitas negatif, seperti melakukan aktivitas lain yang tidak relevan dengan kegiatan pembelajaran merupakan indikasi bahwa aktivitas siswa pada pembelajaran biologi dengan menggunakan model pembelajaran berbasis masalah meningkat.

Rendahnya aktivitas belajar siswa pada siklus I disebabkan karena para siswa masih belum dapat beradatasi dengan model pembelajaran yang digunakan. Siswa pada umumnya masih terpengaruh dengan model pembelajaran yang berpusat pada guru dan keaktifan siswa yang masih didominasi oleh siswa yang pintar. Sedangkan pada siklus II, siswa sudah bisa beradaptasi dengan model pembelajaran yang digunakan yaitu model pembelajaran berbasis masalah.

Peningkatan aktivitas belajar siswa dari siklus I ke siklus II memberikan kontribusi positif pada peningkatan kemampuan pemecahan masalah dan hasil belajar kognitif siswa. 


\subsubsection{Hasil Belajar Kognitif Biologi}

Secara deskriptif hasil penelitian ini juga mengungkapkan bahwa hasil belajar kognitif biologi siswa kelas $\mathrm{VII}_{\mathrm{A}}$ SMP Negeri 4 Wonomulyo yang mengikuti pembelajaran dengan model pembelajaran berbasis masalah pada siklus II, termasuk dalam kategori amat baik, baik, cukup, dan sedang. Hasil penelitian ini di dukung oleh besarnya persentase siswa yang mendapat nilai pada interval $65-84$ yaitu 63,33\% atau sebanyak 19 orang siswa dari 30 siswa. Nilai rata-rata kelas yang diperoleh pada siklus II adalah 78,33 yang berada pada interval tinggi. Pada siklus I didapatkan siswa yang memperoleh nilai pada kategori sangat tinggi dan masih didapatkan siswa yang memperoleh nilai pada kategori rendah yaitu sekitar 20\% atau sekitar 6 orang siswa dari 30 orang siswa. Di siklus II didapatkan siswa yang memperoleh nilai pada kategori sangat tinggi yaitu sekitar $26,67 \%$ dan sudah tidak ditemukan siswa yang memiliki nilai pada kategori rendah. Jadi, secara umum dapat dikatakan bahwa terjadi peningkatan hasil belajar kognitif biologi siswa yang belajar dengan menggunakan model pembelajaran berbasis masalah di SMP Negeri 4 Wonomulyo.

Nilai hasil belajar kognitif biologi siswa kelas $\mathrm{VII}_{\mathrm{A}}$ SMP Negeri 4 Wonomulyo meningkat dari siklus I ke siklus II. Pemberian kuis di setiap akhir pertemuan tentang materi ekosistem dalam proses pembelajaran dan tingkat kesulitan yang berbeda pada setiap pertemuan juga ikut mempengaruhi nilai hasil akhir belajar biologi siswa. Selain itu, keberhasilan siswa mencapai nilai Kriteria Ketuntasan Minimal juga di dukung oleh semua aktivitas siswa yang mengalami peningkatan dari siklus I ke siklus II, yaitu siswa memperhatikan penjelasan guru, mendefenisikan masalah yang dihadapi, membaca dan mengerjakan tugas LKS dengan cermat, bekerja sama dengan kelompok, menyajikan hasil karya, memberikan pertanyaan pada saat diskusi antar kelompok, memberikan jawaban pada saat diskusi antar kelompok, dan menyimpulkan materi pelajaran.

Perubahan tingkah laku yang terjadi akibat proses belajar mengajar disebut sebagai hasil belajar, sementara yang ingin dicapai dalam proses pembelajaran adalah adanya perubahan tingkah laku orang yang belajar. Terbentuknya tingkah laku sebagai hasil belajar mempunyai tiga cirri pokok yaitu: tingkah laku tersebut berupa kemampuan aktual, kemampuan berlaku dalam waktu relatif lama, kemampuan diperoleh melalui usaha. Model pembelajaran berbasis masalah dapat menciptakan kondisi belajar yang menyenangkan dan menumbuhkan keberanian untuk menyumbangkan ide atas satu permasalahan yang ada sehingga siswa lebih aktif dalam proses pembelajaran dan lebih memotivasi siswa untuk belajar. Semakin besar motivasi dan keinginan siswa untuk berhasil dalam belajar, maka semakin besar pula usaha yang dilakukan siswa agar memperoleh hasil belajar yang lebih baik. Keaktifan siswa dalam proses pembelajaran menyebabkan siswa menjadi lebih memahami materi pelajaran dan berdampak pada meningkatnya hasil belajar siswa. Hal ini sesuai dengan hasil penelitian yang dilakukan oleh Siswanto (2012), bahwa Pembelajaran Berbasis Masalah dapat meningkatkan hasil belajar kognitif siswa.

Sejalan dengan hal tersebut, Keller (dalam Abdurrahman (1999) mengatakan bahwa ada dua faktor yang mempengaruhi hasil belajar, yaitu: (1) faktor yang berasal dari dalam diri siswa meliputi: motivasi dan harapan untuk berhasil, intelegensi, dan penguasaan awal siswa, serta evaluasi kognitif tentang kewajaran dan keadilan; (2) faktor yang berasal dari lingkungan meliputi: rancangan pengelolaan motivasi dan rancangan pengelolaan kegiatan pembelajaran. Motivasi dan harapan untuk berhasil serta rancangan pengelolaan motivasi tidak berpengaruh langsung terhadap hasil belajar tetapi berpengaruh pada usaha yang dilakukan siswa untuk memperoleh hasil belajar. Usaha adalah indikator dari adanya motivasi, sedangkan hasil belajar dipengaruhi oleh besarnya usaha yang dilakukan oleh siswa untuk memperoleh hasil belajar yang lebih baik. Jadi, semakin besar motivasi dan keinginan untuk berhasil dalam belajar, maka semakin besar pula usaha yang dilakukan untuk memperoleh hasil belajar yang lebih baik.

Berdasarkan data hasil penelitian di atas menunjukkan bahwa penggunaan model pembelajaran berbasis masalah dalam pembelajaran biologi di sekolah dapat memberikan kontribusi terhadap aktivitas, respon, kemampuan pemecahan masalah, dan hasil belajar kognitif biologi siswa kelas $\mathrm{VII}_{\mathrm{A}}$ SMP Negeri 4 Wonomulyo.

\section{KESIMPULAN}

Berdasarkan hasil analisa data dan pembahasan maka dapat disimpulkan bahwa: (1)Penggunaan model pembelajaran berbasis masalah dapat meningkatkan aktivitas belajar siswa pada materi 
ekosistem siswa kelas VII $_{\mathrm{A}}$ SMP Negeri 4 Wonomulyo dengan nilai rata-rata pada siklus I sebesar 65,63 dan pada siklus II meningkat menjadi 87,71, (2)Penggunaan model pembelajaran berbasis masalah dapat meningkatkan hasil belajar kognitif biologi siswa pada materi ekosistem siswa kelas $\mathrm{VII}_{\mathrm{A}}$ SMP Negeri 4 wonomulyo dengan nilai rata-rata pada siklus I sebesar 62,33 dan pada siklus II meningkat menjadi 78,33.

\section{DAFTAR PUSTAKA}

Abdurrahman, M. 1999, Pendidikan Bagi Anak Berkesulitan Belajar, Rineka Cipta, Jakarta.

Arends, R. I. 2004, Learning to Teach. Sixth Edition, Mcgraw Hill, New York.

Arikunto, S. 2003, Dasar-dasar Evaluasi Pendidikan, PT. Bumi Aksara, Jakarta.

Arnyana, I. B. P. 2004. Pengembangan Perangkat Model Belajar Berasarkan Masalah di pandu Strategi Kooperatif serta Pengaruh Implementasinya terhadap Kemampuan Berpikir Kritis dan Hasil Belajar Siswa Sekolah Menengah Atas pada Pelajaran Ekosistem. Disertasi tidak diterbitkan. Malang: Universitas Negeri Malang.

Badan Standar Nasional Pendidikan (BSNP). 2007. Model Penilaian Kelas. Kurikulum Berbasis Kompetensi untuk Sekolah Menengah Pertama. Jakarta: Departemen Pendidikan Nasional.

Badan Standar Nasional Pendidikan (BSNP). 2008. Standar Isi untuk Satuan Pendidikan Dasar dan Menengah, Standar Kompetensi dan Kompetensi Dasar SMP/MTs. Jakarta.

Bloom, B.S.1979. Taxonomy of Education Objectives. Book I Cognitif Domain. London: Longman Group Ltd.

Depdiknas. 2003. Permendiknas No. 23 Tahun 2006. Standar KompetensiLulusan. Jakarta : Depdiknas

Depdiknas. 1991. Kamus Besar Bahasa Indonesia. Jakarta : Balai Pustaka.

Djamarah. 2002. Guru dan Anak Didik dalam Interaksi Edukatif. CetakanPertama. Jakarta: Rineka Cipta

Djamarah. 2006. Strategi Belajar Mengajar. Jakarta: Rineka Cipta

Hadis, A. Psikologi dalam Pendidikan. Bandung: Alfabeta

Haling. 2006. Belajar Dan Pembelajaran. Makassar: Badan Penerbit UNM.

Hamalik. 2002. Pendidikan Guru Berdasarkan Pendekatan Kompetensi. Bandung: Bumi Aksara.

Hamalik, 2005. Proses Belajar Mengajar. Jakarta: Bumi Aksara.

Hasibuan, 2000. Manajemen Sumber Daya Manusia. Jakarta : Bumi Aksara.

Huda, M. 2011. Cooperatif Learning. Metode, teknik, Struktur dan Model Pembelajaran. Yogyakarta: Pustaka Pelajar.

Ibrahim, M, dkk. 2000. Pembelajaran Kooperatif. Surabaya: UNESA University Press

Ibrahim, M. Dkk. 2005. Pembelajaran Kooperatif. Surabaya: UNESA University Press

Ibrahim \& Nur, M. 2000. Pengajaran Berpusat pada Siswa. Surabaya: UNESA, University Press.

Muhkal, M. 2005. Pengembangan Program Pembelajaran Matematika. Makassar Jurusan Matematika FMIPA UNM.

Mulyasa, 2002. Kurikulum Berbasis Kompetensi. Bandung: PT Remaja Rosdakarya.

Purwanto. 2011. Evaluasi Hasil Belajar. Yogyakarta: Pustaka Pelajar

Ratumanan, T. G. 2004. Belajar dan Pembelajaran. Surabaya: Unesa University Press.

Ruslan, 2009. Validasi isi Buletin Pa'biritta No.10 Tahun VI September 2009

Rusman. 2010. Model-Model Pembelajaran Mengembangkan Profesionalisme Guru, Jakarta: PT Rajagrafindo Persada.

Sadirman, 2001. Belajar Secara Efektif dan Efisien. Jakarta: Rineka Cipta

Sadirman. 1996. Interaksi dan Motivasi Belajar Mengajar (ed.rev) Jakarta:Raja Grafindo Persada.

Sagala, S. 2008. Konsep dan Makna Pembelajaran. Bandung: Alfabeta.

Sanjaya. 2009. Kurikulum Dan Pembelajaran. Jakarta: Prenada Media

Sanjaya, W. 2007. Strategi Pembelajaran. Jakarta: Kencana

Sanjaya, W. 2010. Strategi Pembelajaran Berorientasi Standar Proses Pendidikan. Jakarta: Prenada Media

Siswanto. 2012. Pengaruh model Problem Based Learning (PBL) terhadap kemampuan memecahkan masalah dan hasil belajar kognitif Biologi siswa kelas VII SMP Negeri 14 Surakarta. 


\section{JURNAL SAINTIFIK VOL 1 NO. 1 JANUARI 2015}

Skripsi (tidak diterbitkan). Fakultas Keguruan dan Ilmu Pendidikan. Universitas Sebelas Maret.

Slameto. 2003. Belajar Dan Faktor-Faktor Yang Mempengaruhinya. Jakarta: Rineka Cipta

Slavin, R. 2009. Cooperatif Learning, Teori, Riset dan Praktek. Bandung: Nusa Media

Sugiyono. 2010. Metode Penelitian Pendidikan Pendekatan Kuantitatif, Kualitatif,dan $\quad R \quad \& \quad D$. Bandung: Alfabeta.

Suparno. 1997. Filsafat Konstruktivisme dalam Pendidikan. Yogyakarta: Kanisius.

Tilaar, R. 2002. Membenahi Pendidikan Nasional. Jakarta: Rineka Cipta

Trianto. 2009. Model-Model Pembelajaran Inovatif Berorientasi Konstruktivistik. Jakarta: Prestasi Pustaka Publisher

Trianto. 2010. Mendesain Model Pembelajaran Inovatif-Progresif. Jakarta: Kencana Prenada Media Group

Uno, H. 2011. Model Pembelajaran. Jakarta: Bumi Aksara.

Uno, H. B. 2007. Statistik untuk Penelitian. Bandung : Alfabeta

Yusuf. 2007. Pembelajaran Kooperatif. Jurnal Ilmu Pendidikan (online) (http//:www. damandiri.or.id/file/ yusufunsbab2.pdf. Diakses tanggal 15 Mei 2013). 